\section{Pavlenchyk N., Horbonos F., Pavlenchyk A., Skrynkovskyy $\mathbf{R}$.}

\title{
RESEARCH OF COMPETITIVENESS OF THE ENTERPRISE ON THE PRINCIPLES OF STRATEGIC PLANNING
}

Об’єктом дослідження є економічні прощеси, які забезпечують створення належних умов формування конкурентоспроможності підприємства на засадах стратегічного планування. Найбільш проблемними моментами при формуванні конкурентоспроможності є формулювання ї̈ критеріїв з позицї сильних і слабких сторін потенціалу підприємства, а також можливостей $i$ загроз, які воно може мати в зовнішньому середовищі. А також, труднощі дослідження рівня негативного впливу зовнішніх чинників конкурентоспроможності об'єктивного характеру.

Дослідження проведені із застосуванням діалектичного підходу, згідно якого сукупність кількісних та якісних характеристик підприємства в єдності з економічними відносинами, розглядається як умова збільшення обсягів виробнищтва конкурентоспроможної продукиї, на засадах стратегічного планування. За допомогою комплексного підходу вибудовано кониептуальну модель впливу стратегічного планування на рівень конкурентоспроможності підприємства.

В ході дослідження визначено, що ринковий механізм, в умовах якого функціонують підприємства, не в змозі створити конкурениію чи конкурентне середовище, оскільки виробництво продукту здійснюється не ринком, а господарюючими суб'єктами. Відтак, конкуренцію доцільно розглядати, як основоположний засіб реакції ринку, на необхідність врегулювання ситуаџї протистояння на ньому.

Конкурентоспроможність підприємства доцільно трактувати як сукупність його якісно-кількісних ресурсних параметрів та чинників, які за співставимими умовами, або наближених до них, з іншими підприємствами забезпечують виробництво конкурентоспроможної продукції.

Авторами удосконалено трактування терміну «стратегічне планування». Стратегічне планування це системний, чітко скоординований шлях до управління змінами, з метою досягнення гармонійного розвитку підприємства та формування спільного бачення його майбутнього. Це взаємоузгоджений механізм окреслення та визначення проблем, погодження реалістичних цілей, завдань і стратегій, реалізація яких сприятиме їх вирішенню та формуванню конкурентоспроможності підприємства.

Визначено основні професійні компетениї головного менеджера, які відображають інтегрований результат взаємодї його фахових навиків та безпосередньо впливають на ефективність формування стратегічного плану.

Ключові слова: конкурентне становище підприємства на ринку, конкурентоспроможність підприємства, стратегічне планування, професійні компетениї менеджера.

\section{Introduction}

Under market conditions, the efficiency of enterprises is largely due to their financial and economic prospects, profitability and competitiveness. It is competitiveness that determines the ability of an enterprise to sell such goods or services, the consumer attractiveness of which is higher than similar ones offered by competitors. Consequently, the strategy for the continued existence and development of the enterprise should be focused on reducing individual costs and increasing the volume of production of quality products. Only high quality products will be in demand, which ultimately will lead to an increase in profitability and form the competitiveness of the enterprise. Strategic planning as a factor in improving competitiveness reflects an organized mechanism for managing changes in the organization of production and labor. And also, the formation of a single common vision of its economic future and development, a harmonious process of identifying problems and agreeing on realistic goals and objectives for solving them. It is the powerful tool that has a positive effect on the production and organizational microclimate of the enterprise, its competitive position in the market.

Determining the economic opportunities and problems of an enterprise in achieving its long-term goals, increasing its competitiveness on the basis of the chosen strategy determines the relevance of the problem of skillful use of the provisions and principles of strategic planning.

\section{The object of research and its technological audit}

The object of research is the economic processes that ensure the creation of conditions for the formation of competitiveness of an enterprise on the basis of strategic planning.

The development strategy involves the concentration of efforts to achieve production objectives in the shortest possible time, with minimal cost and most effective for the enterprise. Accordingly, the production of competitive products, which precisely forms the competitiveness of an enterprise, depends on: 
- use of innovative methods and approaches in the preparation of strategic development plans;

- ability of the chief manager to apply professional competence in determining alternative ways to minimize the risks of the market environment;

- improving the competitive advantages of the enterprise.

The most problematic moments in the formation of competitiveness are the formulation of its criteria for the position of the strengths and weaknesses of the enterprise, as well as the opportunities and threats it may have in the external environment. And also, the difficulties of studying the level of negative impact of external factors of competitiveness of an objective nature.

\section{The aim and objectives of research}

The aim of research is studying and substantiating the organizational and economic bases of strategic planning, as an internal factor in the formation of competitiveness of an enterprise.

To achieve this aim it is necessary to solve the following tasks:

1. To determine the economic nature of competition as an economic phenomenon.

2. To explore the concept of enterprise competitiveness.

3. To substantiate strategic planning, as one of the means of forming competitiveness.

4. To build a model of the impact of strategic planning on the level of formation of competitiveness of the enterprise.

5. To highlight the competencies of the chief manager, who directly affect the effectiveness of the formation of the strategic plan.

\section{Research of existing solutions of the problem}

In the scientific literature there are various methodological approaches to understanding the competitiveness of an enterprise and the determination of factors influencing its formation. However, their research was mainly aimed at determining the competitiveness of enterprises in the context of their competitive advantages, which were determined by the level of resources and the ability to use them. Thus, representatives of the theory of price competition are the authors of [1,2], who based this definition mainly on factors of production, its scope and technology. However, with this approach, not enough attention was paid to the final result of the interaction of these factors, namely the production of high-quality products, as well as the influence of the managerial factor.

An interesting approach is presented in [3], where the author interprets competitiveness at the same time as the result of competitive struggle, as well as the basis for the development of the economy of an individual business entity and society as a whole. At the same time, the author focuses on the importance of victory in the economic struggle, because it is this that will enable to function and develop.

The original is the methodological approach presented in $[4,5]$. The authors of these works consider competitiveness as a superior property of a product or subject over similar ones in the market. According to this statement, it is possible to compete for subjects with their goods or services only at the stage of commodity-money exchange, and the process of their production does not count.

The interpretation of the competitiveness of an enterprise in [6], in which the author regards it as the ability to maintain its position in the market and dynamically develop in the conditions of tough competition, is somewhat voluminous and multifaceted. At the same time, the author notes that an enterprise can win a fight in the conditions of production of goods and services with high consumer value, high innovative activity, efficiency of resource use and adaptability to changes in the external environment.

One of the representatives of the theory of management in work [7] believes that competition is the struggle of producers for economic resources and strengthening their position in the market. The main thing in this struggle, the author sees in the introduction of innovations, changes in the organization of labor and production, and the main factor that determines the competitiveness of the enterprise is the ability of managerial personnel to implement them. At the same time, the resource support of the enterprise, its potential and the organization of production remain without attention.

The generalization of the results of scientific-theoretical and applied research of scientists shows that, despite the presence of significant developments, not all aspects of the problem are adequately studied. Not enough attention is paid to the study of the competitiveness of an enterprise from the standpoint of the conditions that shape it, in particular the increase in the output of competitive products based on strategic planning, as the basis for generating a competitive strategy.

The development of domestic enterprises largely depends on the growth of their competitive potential, ability to solve problems of legal regulation of economic competition protection, based on rational management decisions, compliance with the basic requirements and stages of strategic planning. Researches of scientists emphasize the features, task, role, mission, goals and meaning of strategic planning in the functioning of enterprises.

Thus, in $[8,9]$, strategic planning is reduced only to a decision-making mechanism that corresponds to the goals. However, with this approach, strategic planning becomes somewhat instantaneous, since the decision can be made spontaneously. At the same time, the content of the strategy appears as contradictory, as a certain longterm, planned activity.

Similar are the approaches reflected in the works $[10,11]$, in which the authors consider strategic planning as actions and approaches of management personnel. In this case, the focus is on the manager's ability to respond to changes in the external environment in time and the weight and influence of internal problems of the enterprise is somewhat reduced.

An interesting methodical approach is specified in [12], where the strategy is viewed as «...creating a unique and advantageous position, providing for a specific set of activities». In this case, the author focuses on the role and importance of the marketing strategy of the enterprise for its development. With this approach, in the overall development strategy of the enterprise, the share of its production activities and participation of management personnel in these processes is somewhat reduced.

Thus, the study of the socio-economic foundations of strategic planning, which thoroughly reflected its content, as a means of enterprise development strategies and enhancing 
its competitiveness is still insufficient and requires further development.

\section{Methods of research}

Studies conducted using a dialectical approach to the investigated phenomena. According to it, a set of quantitative and qualitative characteristics of an enterprise in unity and interrelation with economic relations is considered as a condition for increasing the production volumes of competitive products, based on strategic planning.

In the process of scientific research on the competitiveness of enterprises, a systematic approach is applied using elements of the dialectical method of scientific cognition: comparison, systematization, logical generalization to analyze the views and approaches of scientists and clarify the concepts of «competition» and «enterprise competitiveness». Using an integrated approach, a conceptual model of the influence of strategic planning on the level of enterprise competitiveness is built.

\section{Research results}

The main reason for the emergence of competition is the freedom of choice by enterprises-producers of a certain type of activity. Given this, manufacturers can dynamically change the range, production volumes and product quality, and therefore, in conditions of high competition of a certain type of product, manufacturers can produce another product with a smaller number of competitors. Competition of commodity producers is one of the important elements of the market mechanism and at the same time a fundamental attribute of the market. This is the condition under which market mechanisms operate, generating price signals, generating incentives, shaping market wealth, a variety of products and high quality products and services. It is an economic competition for manufacturers of the same products on the market, aimed at attracting as many consumers as possible, thanks to this - obtaining the maximum benefit [13]. This shows that the competition of producers should motivate the production of the range and of such quality, which caused a high level of preference and prompted consumers to the need to purchase it.

The task that some manufacturers set for themselves in the market is to emerge as the winner in competition with other manufacturers of identical products in winning the commitment of the consumer and to get a steady profit on this basis. «Competition means economic rivalry between separate producers of products, works, services to meet the interests associated with the sale of products, the performance of works, the provision of services to the same consumers» [14, P. 229]. But it is advisable to consider competition as an economic phenomenon, and an economic phenomenon is nothing but a change in relations.

Another approach to understanding the concept of competition was formed by the author of a scientific work [7], who believes that competition is an incentive for minimizing costs and maximizing profits. According to the author, competition opens up new opportunities for improving production conditions, changes the structure of relations between producers, supply and demand, conditions for the formation of production costs and prices [15].

The position of the importance of the existence of competition belongs to the author of labor [1]. In stu- dies, the author proves that, thanks to free competition of entrepreneurs and through their own interests, issues are better solved, with the greatest possible benefit both for society and for each of them.

Competition is an important means of control in a market economy. The main competition is between individual producers, individual consumers, individual sellers and individual buyers. The most important function of competition in a market economy is its direct influence on the pricing process. The peculiarity of competition in modern conditions is manifested in the fact that the range of subjects that enter into competitive ties has changed significantly. Because of this, there are competitive relations in the market not only between producers, but also relations between producers and consumers. And manufacturers, in order to attract consumers, are trying to balance the price. This predetermines the main task of competition - to assist commodity producers in the struggle for the consumer to conquer the market, defeat their competitors and ensure a stable income.

The market itself is unable to create competition or a competitive environment, since the production of a product is not carried out by the market, but by enterprises. Therefore, it is advisable to consider competition as a fundamental means of market reaction; the need for resolving the situation of confrontation is due to the emergence of a different format of relations and interaction. This form of relationship is manifested due to the entry of new participants and, accordingly, to establish a new balance between the elements of the market mechanism [16].

The positive effect of competition manifests itself when certain favorable conditions are created for its action. The most important condition for the functioning of the competition mechanism is equality and equality of economic agents operating in the market. Here, the number of manufacturers of a similar product and the number of its consumers have the same weight of influence, and the competitiveness of an enterprise plays an important role. In the published results of economic research, one can find many attempts to isolate from the masses and define the concept of enterprise competitiveness, but there is still no unified approach and interpretation of this definition.

According to the interpretation of the electronic free encyclopedia, the competitiveness of an enterprise is «the ability of an enterprise to create, produce and sell goods and services, the price and non-price qualities of which are more attractive than in similar products of competitors. A firm's competitiveness can be defined as its comparative advantage over other firms in the same industry within the national economy and beyond» [17]. Specific in this interpretation is that it is observed a certain «sectoral» limitations of the enterprise in the manifestation of its competitive advantages and does not take into account the positive prerequisites that are determined by its resource potential.

The original definition of enterprise competitiveness is presented by the author of labor [18], who believes that «enterprise competitiveness is a characteristic of an enterprise, reflecting the degree of realization of its actual and potential ability to form, retain and use sustainable competitive advantages» [18]. It is necessary to agree with the author that the competitive advantages of an enterprise, which are formed and determined by the efficiency of the use of available resources, are the basis for the formation of its competitiveness as a whole. Such 
an understanding of enterprise competitiveness is on the same plane as M. Porter's competitive advantage theory, which noted that «the only thing on which the concept of competitiveness can be based at the country level is the efficiency of resource use» [12].

Thus, the results of the analysis of the methodological approaches allow to conclude that the competitiveness of an enterprise is a combination of its qualitative and quantitative resource parameters and factors that are comparable with conditions, or close to them, with other enterprises provide for the production of competitive products. It is such products that, according to quality and expenditure indicators, form the mechanism of higher financial stability against risks in a market environment.

The concept of the competitiveness of enterprises is a relative category of the reliability of the measurement of which consists and is due only to the release of such a product, the qualitative characteristics of which form its advantage in the market over a similar product of competing manufacturers. Therefore, competition in the market can make any kind of product only in comparison with another. The presentation, packaging, positive characteristics of quality indicators not only confirm the commendable certification of products in comparison with the same type, but also provide a basis for recommending its mass delivery to the market, in order to fully meet the demand of the population. Thus, the fact of creating conditions for the formation of competitiveness of an enterprise and its products and, as a result, the manifestation of competition as an economic phenomenon, are important fundamental attributes of the market mechanism.

Competitiveness of the enterprise in the market conditions is enhanced by the action of the economic laws of supply and demand. At the same time, the intentions of each of the participants are simultaneously under the objective and subjective influence of their actions, which leads and determines more or less successful. Under such conditions, the action of the «invisible hand» should manifest itself in the market environment. Wherein «the objective laws of a market economy operate independently of the will and desires of individuals, spontaneously ensure the harmony of interests of the individual ... and harmonize the economic interests of business entities ...» [1].Globalization processes occurring in the global economy and cause a new way of thinking among entrepreneurs seeking to improve the competitiveness of their enterprise.

Modern complex competitive conditions for the functioning of enterprises of various legal forms of ownership require their managers to be dynamic and optimal in the process of managing an enterprise and making important decisions. Uncertainty in their abilities, fear of violating certain objectively and subjectively established rules of managing the market, and therefore the threat to lose competitive advantages, restrain the entrepreneur in taking decisive steps, weaken its initiative. After all, it is precisely the ability and ability of a manager to assess the production and business situation, foresee and minimize risks, make the right, optimal management decision, outline a strategic development plan directly affects production efficiency, enterprise sustainability and the formation of its competitiveness.

Today's conditions of risk and uncertainty within the limits of the complication of the structure of market relations require managers of enterprises to search (or form) a qualitatively new approach to diagnostics in the enterprise management system. At the same time, management decisions should be directed at eliminating problems and/or using the chances of the external and internal environment of the enterprise in the context of its development and the formation of prospects.

In this regard, to improve the competitiveness of the enterprise, strategic planning becomes one of the most important means of strategic management. Strategic management should be considered as a set of social, economic and industrial relations associated with the development, formation and implementation of the enterprise development strategy with the participation of its managers at all levels [19, 20].

Under such conditions, the head of the enterprise, not only accepts the challenge of the competitive environment, but fulfills the functions of a manager, takes full responsibility for the decisions made. Making optimal decisions is based on an assessment of the business environment and determines the formation of appropriate strategies as components of strategic planning. Strategic planning involves the process of managing the activities of the enterprise, with the aim of achieving internal excellence and balance between its goals, objectives and the possibilities of their implementation and achievement. It plays a coordinating role in the development of an enterprise, provides an opportunity to solve or prevent certain problems, directs activities towards the achievement of objectives, and the like.

It is strategic planning that is a powerful means of uniting enterprise employees of all management levels, which has a positive effect on the internal business climate, the competitive position of an enterprise and is a means of solving problems associated with its improvement. In the conditions of its reasonable implementation, strategic planning predetermines the use of such tools and levers of economic development, most correspond to the outlined task. In particular, such tools include the creation and maintenance of a favorable business climate in an enterprise, marketing research, innovation and investment activity, rational use of resources, etc.

The strategic plan allows the enterprise to realize its individuality, both from the point of view of employees and from the point of view of the environment. Achieving these goals unites all workers in various functional structures, emphasizes the importance of their work. Such plan coordinates their activities, helps to optimally allocate resources and, as a result, directly affects the formation and increase of the level of competitiveness of the enterprise (Fig. 1).

The choice of a specific strategic model is based on the output system conditions from which the planning process begins and on which the chosen scale and level of the plan depends. The main goal of the strategic planning process is the preparation and formation of an integrated, integrated long-term plan, which is aimed at shaping the competitiveness of an enterprise and the stages of its development.

In modern economic conditions, characterized by instability and dynamism, in the process of developing a strategic plan that will enhance the competitiveness of the enterprise, the main role is assigned to the chief manager. It should focus on several important points, the omission of which can lead to the loss of not only the competitive advantages of an enterprise in the market, but also its financial independence. It should be borne in mind that it is on the 
professional qualities of a manager, on its competence, the effectiveness of current and advanced planning.

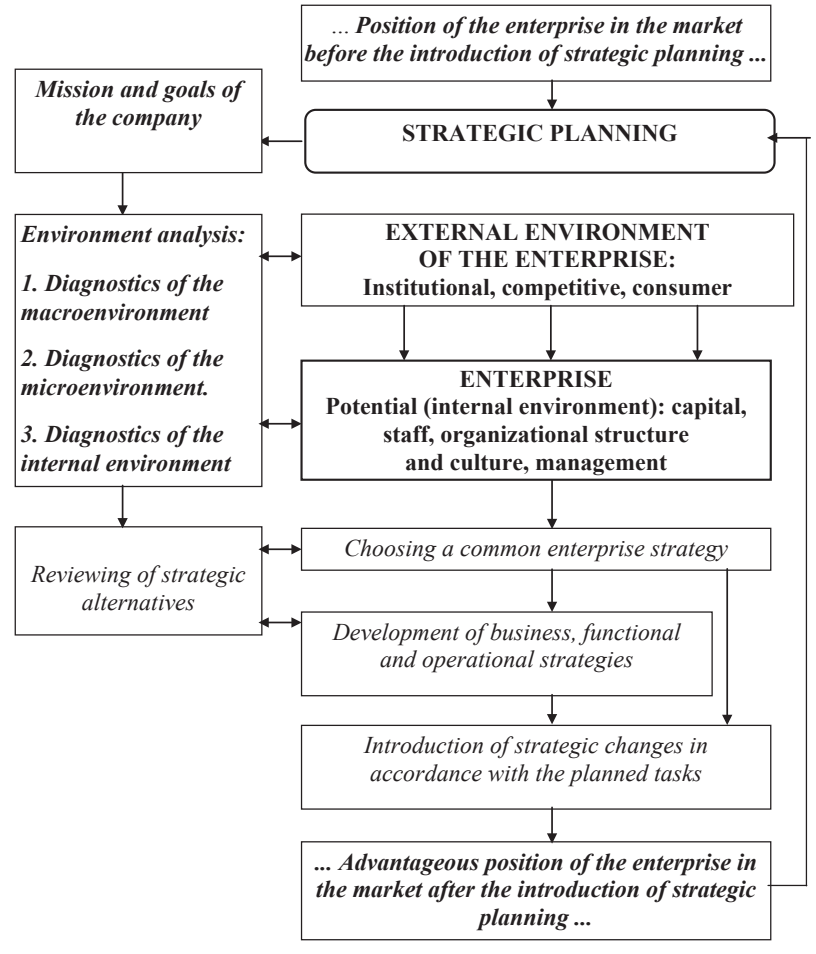

Fig. 1. The model of the impact of strategic planning on the formation and competitiveness degree of the enterprise

Let's propose to highlight several main subjective professional competencies of the main manager, which directly affect the effectiveness of the formation of a strategic plan.

One of the important managerial competencies in the production of strategic planning is the ability of the manager to see the capabilities of the enterprise, which reflect a set of positive-favorable factors of the internal and external environment. Particular attention should be paid to the manager to efficiently and rationally solve the tasks of specialization and location of production, determining the size of an enterprise, and the possibilities of introducing innovative technologies and systems of organizing labor and production. The best mechanism to generalize and streamline the results of the analysis of these factors is the formation of a SWOT-matrix.

The next competence required in the formation of a strategic plan is the ability of a manager to single out the main thing and concentrate all attention on it. The effectiveness of management, as an element of the relations of production, is due to the fact that it must be constantly aimed at the effective use of the potential capabilities of each individual employee or division. At the same time, the skill of the manager acquires special importance rationally and clearly set current tasks, which are formulated on the basis of the conditions necessary to solve a specific urgent problem.

Equally important for the effective implementation of the strategy is the manager's ability to simulate the development scenario and apply scaling. The validity and reality of the plan depends on the degree of adequacy of the reflection of the expected result by it, due to the level of knowledge of the mechanism of action of economic and natural laws and taking into account their requirements.
Significant in the moment of modeling the development scenario of the enterprise is the ability to determine the optimal number of promising indicators and the establishment of their economically reasonable values.

Another professional competence, it is advisable to highlight the ability of the manager to identify and select a rational model of the enterprise's entry and its formation in the market. Directly from the decisions of the chief manager depends on the possibility of introducing strategic changes in the enterprise in accordance with the planned tasks. It is the choice of effective strategies and their scientific substantiation that results in the excess of the useful effect over the costs incurred in obtaining it.

The main quality parameter of strategic planning is its effectiveness. Forecasting efficiency is an integral component of long-term planning, since it is the optimality and rationality of strategic decision-making that determine the pace of development of an enterprise and its profitability. Based on the basis of the calculation of economic and financial indicators of the effectiveness of a strategic development plan for an enterprise, the same criteria and indicators should be calculated to analyze the activities of its individual components and divisions.

The fundamental means of managing the effectiveness of a strategic plan are:

- innovative methods of assessing the production and economic activities of the teams of individual departments of the enterprise and its whole;

- improvement of the system of incentives and labor motivation;

- continuous professional development of managers through the passage of exercises, trainings, seminars; - use of high-quality, reliable information and the application of scientific economic and mathematical research methods.

\section{SWOT analysis of research results}

Strengths. The competitiveness of an enterprise is defined as an attribute that is conditioned by the production of high-quality, competitive products. Formation of enterprise competitiveness, its economic development is based on strategies and programs, the implementation of which allows to adapt to economic changes by improving your competitive position, taking into account the decisive factors of production:

- human resources;

- material and technological support;

- information;

- capital.

A model of the influence of strategic planning on the level of enterprise competitiveness is proposed. The main professional competencies of the chief manager, the use of which directly affects the efficiency of the formation of a strategic plan, as one of the factors in the formation of competitiveness of an enterprise, are highlighted.

Weaknesses. Since the strategic plan is the result of complex, teamwork is always a subjective risk associated with the participation of each individual performer in the overall work.

Opportunities. Taking into account the specified competencies of a manager, it is advisable to investigate in more detail the influence of each of them at different stages of the development and drawing up of a strategic plan and determine the level of their interrelation. 
Threats. In modern conditions, the activities of enterprises are accompanied by significant risks, both objective and subjective, in turn represents a significant threat to the formation and effective implementation of strategic plans.

\section{Conclusions}

1. It is established that the market mechanism, under the conditions of which enterprises operate, is not able to create competition or a competitive environment, since the production of a product is carried out not by the market, but by economic entities. Therefore, it is advisable to consider competition as a fundamental means of market reaction to the need to resolve the situation of confrontation due to the emergence of a different format of relations and interaction. This form of relationship is manifested due to the entry of new participants and, accordingly, to establish a new balance between the elements of the market mechanism.

2. Competitiveness of an enterprise is a combination of its qualitatively-quantitative resource parameters and factors that are comparable in terms of, or close to them, with other enterprises provide for the production of competitive products. It is such products that, according to quality and expenditure indicators, form the mechanism of higher financial stability against risks in a market environment.

3. It is substantiated that strategic planning is a systematic, well-coordinated path to change management, with the goal of achieving a harmonious development of the enterprise and forming a common vision of its future. This is a mutually agreed mechanism for identifying problems, agreeing on realistic goals, objectives and strategies, the implementation of which will contribute to their solution. It is aimed at shaping the development strategy of the enterprise, taking into account the dynamic market environment to enhance competitive advantages.

4. It is shown that the choice of a specific strategic model is based on the output system conditions from which the planning process begins and on which the chosen scale and level of the plan depends. The main goal of the strategic planning process is the preparation and formation of an integrated, integrated long-term plan, which is aimed at shaping the competitiveness of an enterprise and the stages of its development. Such a plan coordinates their activities, helps to optimally allocate resources and, as a result, directly influences the formation and increase of the level of competitiveness of the enterprise.

5. The main professional competencies of the chief manager are defined, which reflect the integrated result of the interaction of its professional skills and directly affect the effectiveness of the formation of the strategic plan. It is highlighted that the main professional competencies of the general manager are:

- ability of the manager to see the capabilities of the enterprise, which reflect the totality of positive-favorable factors of the internal and external environment;

- manager's skill to single out the main thing and concentrate all attention on him;

- manager's skill to model the development scenario and apply scaling;

- ability of the manager to identify and select a rational model of the entry of the enterprise and its formation in the market.

\section{References}

1. Smith A. An Inquiry into the Nature and Causes of the Wealth of Nations. CreateSpace Independent Publishing Platform, 2016. 416 p.

2. Ricardo D. The Principles of Political Economy and Taxation. Dover Publications, 2004. 320 p.

3. Ansoff I. The New Corporate Strategy, Revised Edition. Wiley, 1988. 288 p.

4. Porter M. E. Competitive Strategy Techniques for Analyzing Industries and Competitors. Simon \& Schuster Ltd, 2004. 416 p.

5. Treacy M., Wiersema F. The Discipline of Market Leaders: Choose Your Customers, Narrow Your Focus, Dominate Your Market. Basic Books, 1997. 224 p.

6. Fyliuk H. Problemy ta shliakhy pidvyshchennia konkurentospromozhnosti vitchyznianykh pidpryiemstv $\mathrm{v}$ umovakh hlobalizatsii // Visnyk Kyivskoho natsionalnoho universytetu im. Tarasa Shevchenka. Seriia: Ekonomika. 2013. Issue 151. P. 5-8.

7. Schumpeter J. Theorie der wirtschaftlichen Entwicklung.: Eine Untersuchung über Unternehmergewinn, Kapital, Kredit, Zins und den Konjunkturzyklus. Duncker \& Humblot; Auflage, 1997. 369 p. doi: http://doi.org/10.3790/978-3-428-07725-0

8. Ansoff I. Strategic Management Classic Edition. Palgrave Macmillan, 2007. 272 p.

9. Andrews K. R. The Concept of Corporate Strategy. Homewood: Dow Jowes - Irwin, 1971. 245 p.

10. Thompson A. A., Strickland A. J. Strategic Management: Concepts and Cases. Chicago: Irwin, 2000. 928 p.

11. Chandler A. D. Strategi and Structure. Cambridge: MIT Press, Mass., 1962. 287 p.

12. Porter M., Sachs J., McArthur J. Executive Summary: Competitiveness and Stages of Economic Development // Global Competitiveness Report 2001-2002. New York: Oxford University Press, 2001. P. 16-25.

13. Ekonomika pidpryiemstva: textbook / Horbonos F. V. et. al. Kyiv, 2010. 463 p.

14. Ekonomichna teoriia: politekonomiia / ed. by Bazylevych V. D. Kyiv, 2004. 615 p.

15. Ekonomichna entsyklopediia. Vol. 2 / ed. by Mochernyi S. V. et. al. Kyiv: Vydavnychyi tsentr «Akademiia», 2001. 848 p.

16. Pavlenchyk N. F. Rynok silskohospodarskoi produktsii: metodolohichni ta metodychni osnovy formuvannia i funktsionuvannia: monograph. Lviv: Liha-Pres, 2014. 392 p.

17. Konkurentospromozhnist pidpryiemstva. URL: https://uk.wikipedia.org/wiki/Конкурентоспроможність_підприємства (Last accessed: 20.01.2018)

18. Nykolyuk O. Conceptual principles of competitiveness of enterprises // Management Theory and Studies for Rural Business and Infrastructure Development. 2014. Vol. 36, Issue 3. P. 608-615. doi: http://doi.org/10.15544/mts.2014.057

19. Pavlenchyk A. Teoretychni osnovy ta evoliutsiia poniattia «Stratehichnyi menedzhment»// Ekonomika APK. 2011. Issue 18 (1). P. $183-188$

20. Skrynkovskyy R. Diahnostyka stratehichnoho protystoiannia pidpryiemstv-konkurentiv // Biznes Inform. 2016. Issue 5. P. 196-201.

Pavlenchyk Nataliya, Doctor of Economic Science, Associate Professor, Head of the Department of Economics and Management, Lviv State University of Physical Culture, Ukraine, e-mail:pavlinova75@gmail.com, ORCID: http://orcid.org/0000-0001-6164-5644

Horbonos Fedir, Doctor of Economic Science, Professor, Rector, Lviv University of Business and Law, Ukraine, e-mail: fhorbonos@ukr.net ORCID: http://orcid.org/0000-0002-6563-9847

Pavlenchyk Anatolii, PhD, Associate Professor, Department of Economics and Management, Lviv State University of Physical Culture, Ukraine, e-mail: pavlenchyk@bigmir.net, ORCID: http:// orcid.org/0000-0002-2205-1883

Skrynkovskyy Ruslan, PhD, Associate Professor, Department of Business Economy and Information Technology, Lviv University of Business and Law, Ukraine, e-mail: uan_lviv@ukr.net, ORCID: http://orcid.org/0000-0002-2180-8055 